\title{
Peran Objek Wisata Lumpur Lapindo Sidoarjo dalam Meningkatkan Pendapatan Masyarakat
}

\author{
The Role of Lapindo Sidoarjo Lumpur Tourism Object in \\ Increasing Community Income
}

\author{
Indah Noviandari, Mohammad Balafif, Dinda Aprilia \\ Fakultas Ekonomi dan Bisnis Universitas Bhayangkara Surabaya, \\ Jawa Timur, Indonesia
}

DOI: 10.32781/cakrawala.v15i1.368

\begin{tabular}{l}
\hline$\underline{\text { ARTICLE INFO }}$ \\
Peran, \\
Objek Wisata, \\
Pendapatan Masyarakat. \\
Article History: \\
Received : 21 Februari 2021 \\
Accepted : 16 Juni 2021 \\
Publish : 17 Juni 2021
\end{tabular}

Publish : 17 Juni 2021

\begin{abstract}
Abstrak:
Kabupaten Sidoarjo mempunyai salah satu tempat wisata yang strategis dan potensial untuk dikelola, dikembangkan dan dipasarkan. Objek dalam rekreasi berupa wisata Lumpur Lapindo adalah salah satu potensi wisata terbaru yang ada di Sidoarjo. Meski awalnya berupa bencana alam yang menimpa warga Sidoarjo. Wisata lumpur lapindo ini tidak dikelola oleh pemerintah atau dinas yang terkait, namun wisata tersebut dikelola oleh paguyuban warga korban lumpur lapindo yang mata pencaharian yang lama sudah terhenti akibat luapan lumpur lapindo. Tujuan yang hendak dicapai oleh peneliti dalam penelitian ini adalah mengetahui pendapatan masyarakat sebelum dan sesudah ada objek wisata lumpur lapindo, dan mengetahui peran objek wisata lumpur lapindo sidoarjo dalam meningkatkan pendapatan masyarakat. Metode penelitian yang digunakan adalah penelitian lapangan (Field Research) yang bersifat kualitatif. Penelitian ini bersifat deskriptif kualitatif, sedangkan teknik pengumpulan data yang digunakan adalah observasi,wawancara, dan studi dokumentasi.

\section{Abstract:}

Sidoarjo Regency is one of the strategic and potential tourist attractions to be managed, developed and marketed. Recreational nature object in the form of Lapindo Mud tourism is one of the latest tourism potential in Sidoarjo. Although initially in the form of a natural disaster that befell the citizens of Sidoarjo. Lapindo mud tourism is not managed by the government or related agencies, but the tour is managed by a community of Lapindo mudflow victims whose long-term livelihood has been stopped due to Lapindo mudflow. The objectives to be achieved by researchers in this study are to determine the income of the community before and after the Lapindo mud tourism object, and to know the role of the Lapindo Sidoarjo mud tourism object in increasing community income. The research method used is field research that is qualitative. This research is quantitative descriptive, while the data collection techniques used are observation, interviews, and documentation studies.
\end{abstract}

\footnotetext{
${ }^{\otimes}$ Corresponding author :

Address : Jl. Ahmad Yani Frontage Road Ahmad Yani No.114, Kota SBY, Jawa Timur 60231 
PENDAHULUAN

Pariwisata adalah salah satu industri yang mampu menyediakan pertumbuhan ekonomi yang cepat dalam hal kesempatan kerja, pendapatan, taraf hidup dan dalam mengaktifkan sektor produksi lain di dalam negara penerima wisatawan. Berkembangnya pariwisata di suatu daerah akan mendatangkan banyak manfaat bagi masyarakat, yakni secara ekonomi, sosial dan budaya. Namun, jika pengembangannya tidak dipersiapkan dan dikelola dengan baik, justru akan menimbulkan berbagai permasalahan yang menyulitkan atau bahkan merugikan masyarakat. Untuk menjamin supaya pariwisata dapat berkembang secara baik dan berkelanjutan serta mendatangkan manfaat bagi manusia dan meminimalisasi dampak negatif yang mungkin timbul maka pengembangan pariwisata perlu didahului dengan kajian yang mendalam, yakni dengan melakukan penelitian terhadap semua sumber daya pendukungnya (Sukmana, 2017).

Kabupaten Sidoarjo merupakan salah satu tempat wisata yang strategis dan potensial untuk dikelola, dikembangkan dan dipasarkan. Objek alam rekreasi berupa wisata Lumpur Lapindo adalah salah satu potensi wisata terbaru yang ada di Sidoarjo. Meski awalnya berupa bencana alam yang menimpa warga Sidoarjo, tetapi dengan berjalannya waktu masyarakat Sidoarjo dan pemerintahan Sidoarjo bangkit kembali di sektor pariwisata dan mengembangkan potensi wisata baru Lumpur Lapindo Sidoarjo kepada dunia.

Wisata lumpur lapindo tersebut tidak dikelola oleh pemerintah atau dinas yang terkait, namun wisata tersebut dikelola oleh paguyuban warga korban lumpur lapindo yang ingin mencari pencaharian baru karena mata pencaharian yang lama sudah terhenti akibat luapan lumpur lapindo yang sampai saat ini tidak tau pasti kapan luapan lumpur tersebut bisa berakhir.Untuk berkunjung ke wisata lumpur lapindo para wisatawan yang berkunjung mengeluarkan uang sebesar 5.000 rupiah bagi warga sidoarjo dan sekitarnya, untuk wisatawan dari luar kota tarif masuknya berbeda, mereka mengeluarkan uang sebesar 10.000 rupiah. Apabila pengunjung ingin mengetahui lebih detail tentang sejarah asal mula lumpur lapindo, paguyuban wisata lumpur lapindo sudah menyediakan kaset seharga 10.000 rupiah per kasetnya. Pada kawasan lumpur lapindo terdapat beberapa objek yang sudah disediakan untuk pengunjung yang ingin mengelilingi kawasan lumpur lapindo dan melihat secara langsung semburan lumpur lapindo dengan harga 30.000 rupiah per ojeknya.

Berdasarkan permasalahan yang pertama bagaimana pendapatan masyarakat sebelum dan sesudah ada objek wisata lumpur lapindo sidoarjo? dan yang kedua bagaimana peran objek wisata lumpur lapindo sidoarjo dalam meningkatkan pendapatan masyarakat? Oleh karena itu dilakukan penelitian tentang "Peran Objek Wisata Lumpur Lapindo Sidoarjo Dalam Meningkatkan Pendapatan Masyarakat".AdapunTujuanPenelitianini adalah mengetahui pendapatan masyarakat Sebelum dan Sesudah ada Objek Wisata Lumpur Lapindo. Mengetahui peran Objek Wisata Lumpur Lapindo Sidoarjo dalam meningkatkan pendapatan masyarakat.

\section{TINJAUAN PUSTAKA Pengertian Peran}

Menurut Kamus Umum Bahasa Indonesia peran adalah seperangkat tingkat yang diharapkan dimilki oleh orang yang berkedudukan dalam masyarakat. Sedangkan peranan adalah bagian dari tugas utama yang harus dilaksanakan. Sedangkan Peran dalam Kamus Besar Bahasa Indonesia dapat diartikan sebagai peranan, pemain sandiwara atau sesuatu yang jadi bagian yang memegang pemimpin terutama dalam terjadinya hal atau peristiwa. Peranan adalah tindakan yang dilakukan sekelompok 
orang dalam suatu peristiwa, peranan juga merupakan tingkah laku yang diharapkan oleh seseorang yang berkedudukan di masyarakat. Pengertian peranan merupakan aspek kedudukan atau status tertentu dalam masyarakat apabila seseorang melakukan hak dan kewajibannya maka seseorang tersebut sudah menjalankan perannya. Jadi, Peran juga diartikan sebagai tuntutan yang diberikan secara struktural (norma-norma, harapan, tabu, tanggung jawab dan lainnya). Dimana didalamnya terdapat serangkaian tekanan dan kemudahan yang menghubungkan pembimbing dan mendukung fungsinya dalam mengorganisasi. Peran merupakan seperangkat perilaku dengan kelompok, baik kecil maupun besar, yang kesemuannya menjalankan berbagai peran. (Lantaeda, 2017).

\section{Pengertian Pariwisata}

Aktivitas pariwisata merupakan sektor yang memegang peranan penting dalam upaya pembangunan dan pengembangan wilayah dengan berkontribusi terhadap pendapatan suatu daerah (Rudi Biantoro, 2014). "Pariwisata adalah suatu perjalanan yang dilakukan untuk sementara waktu, yang diselenggarakan dari suatu tempat ke tempat lain, dengan maksud bukan untuk berusaha (business) atau mencari nafkah di tempat yang dikunjungi, tetapi semata-mata untuk menikmati perjalanan tersebut guna bertamasya dan rekreasi atau untuk memenuhi keinginan yang beraneka ragam". Pariwisata adalah keseluruhan kegiatan, proses dan kaitan-kaitan yang berhubungan dengan perjalanan dan persinggahan dari orang-orang di luar tempat tinggalnya serta tidak dengan maksud mencari nafkah. Dari pengertian di atas dapat dikatakan bahwa pariwisata adalah suatu perjalanan yang dilakukan untuk berekreasi atau sifatnya hanya sementara atau sebentar untuk mencari suasa baru dan menghilangkan tekanan bekerja dan bukan untuk mencari nafkah.

\section{Pengertian Pendapatan}

Pendapatan adalah uang yang diterima oleh perorangan, perusahaan dan organisasi lain dalam bentuk upah, gaji, sewa, bunga, komisi, ongkos dan laba. Pendapatan atau upah juga berarti uang yang dibayar oleh orang yang memberi pekerjaan kepada pekerja atas jasanya sesuai perjanjian. Tingkat pendapatan adalah perolehan barang, uang yang diterima atau yang dihasilkan suatu masyarakat tersebut. Tingkat pendapatan masyarakat pada suatu daerah. (Sammeng, 2001).

\section{METODE PENELITIAN}

Pendekatan yang digunakan dalam penelitian ini adalah pendekatan kualitatif. Pendekatan kualitatif adalah metode yang digunakan untuk memahami dan mnafsirkan makna suatu peristiwa interaksi tingkah laku manusia dalam situasi tertentu menurut perspektif peneliti sendiri (Husaini dan Purnomo, 2004). Penelitian ini menggunakan metode deskriptif.Penelitian ini merupakan penelitian lapangan (Field Research) yang bersifat kualitatif. Penelitian kualitatif dapat diartikan sebagai penelitian yang menghasilkan data deskriptif mengenai kata-kata lisan maupun tertulis, dan tingkah laku yang dapat diamati dari orang-orang yang diteliti (Suyanto, 2005).

Pendekatan yang digunakan dalam penelitian ini adalah dengan menggunakan pendekatan kualitatif yang menjelaskan secara detail dan mendalam tentang suatu keadaan dari objek yang diteliti. Jadi peneliti mengidentifikasi masalah didalam objek wisata Lumpur Lapindo. Teknik pengumpulan data dilakukan secara triangulasi (gabungan), analisis data bersifat kualitatif, dan hasil penelitian kualitatif lebih menekankan makna dari 
pada generalisasi (Sugiyono, 2013). Dalam penelitian ini peneliti berusaha menggambarkan objek dan subjek yang diteliti sesuai dengan apa adanya, dengan tujuan menggambarkan secara sistematis, fakta dan karakteristik objek yang di teliti secara tepat. Misalnya pengaplikasian, persepsi dan deskripsi dalam bentuk katakata dan dokumen.

\section{HASIL DAN PEMBAHASAN \\ Gambaran Umum Wisata Lumpur Lapindo Sidoarjo}

Lumpur Lapindo merupakan suatu musibah yang terjadi di Kabupaten Sidoarjo yang disebabkan oleh luapan lumpur panas dari galianminyakbumiyang dikerjakanolehPT. Lapindo Brantas Inc dan diselingi kejadian gempa Jogja sehingga banyak berbagai isu - isu mengenai bencana Lumpur Lapindo ini terjadi karena ulah kelalaian manusia atau terjadi karena adanya gempa Jogja. Pusat semburan Lumpur Lapindo ini terus menyemburkan lumpur panas sehingga menenggelamkan 16 Desa dan 6 Kelurahan dari 3 Kecamatan yaitu Kecamatan Jabon, Kecamatan Tanggulangin, dan Kecamatan Porong, Lumpur Lapindo pertama terjadi pada tanggal 29 Mei 2006 gas yang dimiliki Lapindo Brantas Inc memiliki sumur Panji pada kedalaman sekitar 150 meter.

Pendapatan Masyarakat Sebelum dan Sesudah ada Objek Wisata Lumpur Lapindo sidoarjo.

Pendapatan adalah uang yang diterima oleh perorangan, perusahaan dan organisasi lain dalam bentuk upah, gaji, sewa, bunga, komisi, ongkos dan laba. Pendapatan atau upah juga berarti uang yang dibayar oleh orang yang memberi pekerjaan kepada pekerja atas jasanya sesuai perjanjian. Tingkat pendapatan adalah perolehan barang, uang yang diterima atau yang dihasilkan suatu masyarakat tersebut. Tingkat pendapatan masyarakat pada suatu daerah (Sammeng, 2001).
Peningkatan pendapatan dirasakan oleh masyarakat setelah adanya wisata tersebut. Bahwa perubahan pendapatan pada masyarakat yang pekerjaan pokoknya terkait dengan wisata. Masyarakat yang terdampak oleh Lumpur Lapindo Sidoarjo yang awalnya tidak berpenghasilan atau berpenghasilan kurang dari Rp 500.000 menjadi berpenghasilan lebih dari Rp 1.000 .000 dengan adanya objek wisata tersebut.

\section{Peran Objek Wisata Lumpur Lapindo Sidoarjo dalam Meningkatkan Pendapatan Masyarakat.}

Hampir semua literatur dan kajian studi lapangan menunjukan bahwa pembangunan pariwisata pada suatu daerah mampu memberikan dampak-dampak yang dinilai positif, yaitu dampak yang di harapkan, bahwa peningkatan pendapatan masyarakat, meningkatkan penerimaan devisa, untuk meningkatkan kesempatan kerja dan peluang usaha, meningkatkan pendapatan pemerintah dari pajak dan keuntungan badan usaha milik pemerintah, dan sebagainya ( Pitana dan Gayatri, 2005). Sehingga keberadaan Objek Wisata secara penuh dapat di jalankan sesuai dengan tujuan dan keinginan masyarakat dalam hal menambah pendapatan masyarakat. Menurut James (1994) dan Arliman (2018), peran pariwisata saat ini antara lain adalah pertama, peran ekonomi yaitu sebagai sumber devisa negara. Kedua, peran sosial yaitu, sebagai pencipta lapangan pekerjaan, dan yang terakhir adalah peran kebudayaan yaitu, memperkenalkan kebudayaan dan kesenian.

\section{SIMPULAN}

Lumpur Lapindo merupakan suatu musibah yang terjadi di Kabupaten Sidoarjo yang disebabkan oleh luapan lumpur panas dari galian minyak bumi yang dikerjakan oleh PT. Lapindo Brantas Inc dan diselingi kejadian gempa Jogja sehingga banyak 
berbagaiisu-isumengenaibencanaLumpur Lapindo ini terjadi karena ulah kelalaian manusia atau terjadi karena adanya gempa jogja. Karena akibat dari bencana tersebut, banyaknya antusias masyarakat luar yang ingin tahu bagaimana keadaan dan situasi di area genangan lumpur lapindo. Maka dari itu warga korban mengadakan rapat dan membentuk paguyuban untuk menjadikan bencana tersebut menjadi wisata lumpur lapindo. Keberadaan objek wisata sangat berperan dalam Meningkatkan pendapatan masyarakat khususnya pemuda yang ada di sekitardaerah semburanLumpurKecamatan Porong Sidoarjo. Dari hasil penelitian tentang Peran Objek Wisata Lumpur Lapindo Sidoarjo Dalam Meningkatkan Pendapatan Masyarakat di atas, penulis dapat mengambil beberapa kesimpulan, diantaranya 1) Peningkatan pendapatan dirasakan oleh masyarakat setelah adanya wisata tersebut. Bahwa perubahan pendapatan pada masyarakat yang pekerjaan pokoknya terkait dengan wisata. Masyarakat yang terdampak oleh Lumpur Lapindo Sidoarjo yang awalnya tidak berpenghasilan atau berpenghasilan kurang dari Rp 500.000 menjadi berpenghasilan lebih dari Rp 1.000.000 dengan adanya objek wisata tersebut. 2) Peranan ekonomi ini sangat penting, sangat berpengaruh positif terhadap perekonomian masyarakat sekitar wisata Lumpur Lapindo berupa peningkatan pendapatan, pendapatan yang diperoleh masyarakat berasal dari belanja yang dikeluarkan oleh wisatawan selama berwisata di objek wisata Lumpur Lapindo. 3) Peran sosial berpengaruh positif terhadap perluasan lapangan pekerjaan bagi masyarakat sekitar objek wisata Lumpur Lapindo. 4) Peran Kebudayaan sangat penting dan sangat berpengaruh positif terhadap pendapatan. Dengan adanya setiap kegiatan, seperti ritual dan lainnya dapat memabantu pendapatan masyarakat. Karena dengan adanya acara tersebut wisata lumpur lapindo menjadi ramai dan masyarakat banyak yang memanfaatkan untuk berdagang dan pendapatan menjadi naik drastis. Adat istiadat seperti diatas juga dapat mempererat tali persaudaraan meskipun mereka sudah tinggal beda lokasi. Berdasarkan kesimpulan yang telah dikemukkakan di atas, maka penelitian ini memberikan beberapa saran sebagai berikut, 1) Untuk meningkatkan Paguyuban Objek Wisata Lumpur Lapindo Sidoarjo Dalam Meningkatkan Pendapatan Masyarakat sebaiknya pemerintah segera mengeluarkan peraturan, Paguyuban wisata bisa melaksanakan tugas dan fungsinya sebagaimana mestinya. 2) Bagi masyarakat yang telah meneriman manfaat hendaknya berupaya lagi dalam mempromosikan Objek Wisata Lumpur Lapindo Sidoarjo untuk meningkatkan jumlah pengunjung. 3) Hendaknya pemerintah atau masyarakat lebih giat lagi dalam menjaga kelestarian yang ada di wisata Lumpur Lapindo Kecamatan Porong Sidoarjo.

\section{DAFTAR PUSTAKA}

Arliman S, L. (2018). Peran Investasi dalam Kebijakan Pembangunan Ekonomi Bidang Pariwisata di Provinsi Sumatera Barat. Kanun Jurnal Ilmu Hukum, 20(2), 273294. https://doi.org/10.24815/ kanun.v20i2.10081

Husaini, U., Purnomo, S. A. (2004). Metodologi Penelitian Sosial, Jakarta: PT Bumi Aksara

James. (1994). Pariwisata Indonesia, Siasat Ekonomi dan Rekayasa Kebudayaan. Kanisius. Yogyakarta.

Lantaeda, S. B. (2017). Peran Badan Perencanaan Pembangunan Daerah Dalam Penyusunan Rpjmd Kota Tomohon. Jurnal Administrasi Publik, 4(48). 
Rudi Biantoro, S. M. (2014). Pengaruh Pariwisata Terhadap Karakteristik Sosial Ekonomi Masyarakat pada Kawasan Objek Wisata Candi Borobudur Kabupaten Magelang. Teknik PWK (Perencanaan Wilayah Kota), 3(4), 1038-1047. https://ejournal3.undip.ac.id/ index.php/pwk/article/view/6856

Sukmana, O. (2017). Dominasi dan ketidakadilan negara dan korporasi dalam kasus bencana lumpur Lapindo Domination and injustice of state and corporate in the case of Lapindo mudflow disaster Pendahuluan. Masyarakat, Kebudayaan Dan Politik, 30, 150161. http://dx.doi.org/10.20473/ mkp.V30I22017.150-161

http://ojs.umsida.ac.id/index. php/semnasfi/article/ download/1156/1093https:// hotmudflow. files.wordpress. com/2006/08/dari-atas-2.jpg. https://id.m.wikipedia.org/wiki/ Banjir_lumpur_panas Sidoarjohttps://m.cnnindonesia. com/nomi/20190625172403 92-406332/menilik-kronologistragedi-13-tahun-1umpurlapindohttps://travelingyuk.com/ lumpurm-lapindo/30895https:// www.google.co.id/a mp/s/ ihategreenjello.com/pesonakeindahan-wisata-lumpur-lapindo/ $\mathrm{amp} /$.

https://www.slideshare.net/anisaf7/ dampak-lumpur-lapindo-terhadapkegiatan. 